\title{
Comparison of fine-scale spatial genetic structure of two sympatric Rhododendron shrub species in forest habitat having different seed weights: A case study
}

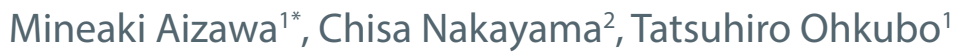 \\ ${ }^{1}$ Department of Forest Science, Faculty of Agriculture, Utsunomiya University, 350, Mine-machi, Utsunomiya, Tochigi \\ 321-8505, Japan \\ 2 Department of Forest Science, Graduate School of Agriculture, Utsunomiya University, 350, Mine-machi, Utsunomiya, \\ Tochigi 321-8505, Japan \\ * Corresponding author: Mineaki Aizawa, E-mail: aizawam@cc.utsunomiya-u.ac.jp
}

\begin{abstract}
Restricted seed dispersal is one of the most prevalent determinants of spatial genetic structure (SGS) at a fine spatial scale within a plant population. Rhododendron kaempferi and $R$. semibarbatum are common and coexistent Ericaceous species in the shrub layer of secondary deciduous broad-leaved forests in the northern Kanto District, central Japan. The two species have entomophilous flowers and are thought to have similar pollination styles. However, R. kaempferi produces threefold heavier seeds than $R$. semibarbatum. Therefore, we tested the hypothesis that the intensity of SGS was stronger in R. kaempferi than in $R$. semibarbatum in a forest stand. We comparatively examined the SGS for 73 individuals of R. kaempferi and 36 individuals of $R$. semibarbatum by using highly variable nuclear microsatellite loci. The analysis revealed significant SGS in both species at the shortest distance $(<3 \mathrm{~m})$; a measure to quantify SGS showed a counterintuitive result: $R$. semibarbatum exhibited stronger SGS than $R$. kaempferi. This result might be explained by the ecological consequences of $R$. semibarbatum producing lighter seeds, which might have greater dispersal efficacy, but its safe sites could be more restricted than those of $R$. kaempferi; in contrast, $R$. kaempferi producing heavier seeds might have more limited seed dispersal, but its safe sites for seedling establishment could be more prevalent than those for R. semibarbatum. The different strategies for the trade-off between seed weight and site selection of the two Rhododendron species might be reflected in the difference in the intensity of SGS in this study plot.
\end{abstract}

Keywords: nuclearmicrosatellite, Rhododendron kaempferi, Rhododendron semibarbatum, seed dispersal

\section{Introduction}

Spatial genetic structure (SGS), the nonrandom spatial distribution of genotypes, in natural populations can result from evolutionary and ecological processes, including random genetic drift, natural selection, and gene flow (Wright, 1943; Epperson, 1992; Loiselle et al., 1995; Vekemans and Hardy, 2004). In addition, intrinsic biological traits (e.g., clonality, breeding systems, life form, and regeneration strategy) as well as extrinsic biological traits (e.g., disturbance and behavior of seed dispersers) are important factors that affect SGS (Chung et al., 2004; Vekemans and Hardy, 2004; Dering et al., 2015). These processes determine in combination, interactively, or solely the intensity and dynamics of SGS. At a fine spatial scale within a plant population, restricted gene dispersal by seeds and pollen is the most prevalent determinant of SGS (Hamrick and Nason, 1996; Chung et al., 2004; Vekemans and Hardy, 2004). Hence, in plant species belonging to the same genus, species producing light seeds can disperse their seeds over longer distances than those producing heavier seeds; therefore, if they have the same pollination style, the former is expected to have a near random spatial structure or lower intensity of SGS than the latter (Chung et al., 2004; Vekemans and Hardy, 2004).

Rhododendron kaempferi Planch. and R. semibarbatum Maxim. are hemideciduous and deciduous shrubs, respectively, belonging to Rhododendron, subgenus Azaleastrum, section Tsutsusi in Ericaceae (Goetsch et al., 2005). The two species are endemic to Japan and are widely distributed from Hokkaido to Kyushu in sunny secondary deciduous broad-leaved forests. The two species are hermaphroditic and have entomophilous flowers. The mean weight of 100 seeds and the mean length of sound seeds are $13.7 \mathrm{mg}$ and $1.31 \mathrm{~mm}$ in R. kaempferi, and $4.5 \mathrm{mg}$ and $0.84 \mathrm{~mm}$ in $R$. semibarbatum, respectively (Nakayama et al., 2016), indicating that $R$. kaempferi produces larger and 
threefold heavier seeds than $R$. semibarbatum. Wang et al. (2014) compared the seed weights of 42 Tibetan Rhododendron species; the seed weights of $R$. kaempferi and $R$. semibarbatum fall within large and small seed weight ranges, respectively, among the Rhododendron species compared in their study. In addition, the number of sound seeds per capsules and number of capsules per individual differ between the species: 55.3 and 6.8 in R. kaempferi and 212.8 and 11.4 in R. semibarbatum, respectively (Nakayama et al., 2016). Thus, we hypothesized that the intensity of SGS was stronger in R. kaempferi that produces a smaller quantity of heavier seeds than that in $R$. semibarbatum that produces a larger quantity of lighter seeds.

Previous studies have shown that clonality affects the SGS of tree species (Suvanto and Latva-Karjanmaa, 2005; Dering et al., 2015). Rhododendron species are reported to commonly exhibit clonal structure through layering (Escaravage et al., 1998; Naito et al., 1999; Mejías et al., 2002; Elliott and Vose, 2012). To remove the effect of clonal structure on the SGS, SGS should be analyzed for one stem from each clone (multi-locus lineage; MLLs) based on clonal identification. However, genotypes of stems sampled from the same clone were not always identical owing to null alleles, genotypic errors, and somatic mutations; therefore, clones can be considered those comprised of slightly different multi-locus genotypes (MLGs; Meirmans and Tienderen, 2004; James and McDougall, 2014). Thus, for clonal identification, we need to determine the mutation threshold value for assigning MLGs to the clones.

Therefore, the goal of this study was to test the hypothesis by using highly variable nuclear microsatellite markers and one stem from each identified clone for the two sympatric Rhododendron species having different seed weights in a forest stand.

\section{Material and Methods}

\section{Study site}

The study was conducted in the Utsunomiya University Forest at Funyu, Tochigi Prefecture, in the northern Kanto District, central Japan. R. kaempferi and R. semibarbatum are common in the secondary deciduous broad-leaved forests and deciduous-red pine mixed forests and are the main components of the Rhododendro-Pinetum densiflorae community in the University forest (Usui, 1966). According to tree survey data (Aizawa unpublished), the mean and maximum heights of the species found in the University forest are $1.7 \mathrm{~m}$ and $2.9 \mathrm{~m}(N=79)$ for R. kaempferi and $1.7 \mathrm{~m}$ and $2.4 \mathrm{~m}(N=29)$ for R. semibarbatum, respectively. The annual mean temperature (1990-2006) was $11.9^{\circ} \mathrm{C}$ and Kira's Warm Index (WI) was $93.2^{\circ} \mathrm{C}$; annual mean precipitation was $1556.7 \mathrm{~mm}$. The forest was characterized by clear weather with relatively little precipitation in winter, which is the common winter climate across the Pacific Ocean side of Japan.

We established a plot $(10 \mathrm{~m} \times 10 \mathrm{~m})$ on a gentle NWN facing slope with a $13^{\circ}$ inclination in a secondary deciduous broad-leaved closed-canopy forest at forest compartment\#6 in the University forest $\left(36^{\circ} 46.680^{\prime} \mathrm{N}, 139^{\circ} 49.507^{\prime} \mathrm{E} ; 320-\mathrm{m}\right.$ altitude), in which Quercus serrata were dominant in the canopy layer and R. kaempferi and R. semibarbatum were dominant in the shrub layer with a small number of $R$. wadanum and $R$. quinquefolium. The age of the forest was 46 years after the latest cutting in 2012. Forest management for the deciduous broadleaved trees, such as cutting for charcoal and litter gathering for compost, has ceased since the 1960s in the University forest; thus, the two Rhododendron species might have been established at that time. We mapped the coordinates of all the stems (length of stem, $\geq 1.0 \mathrm{~m}$ ) that did not have any distinct connection with the roots and creeping stems above the ground using a laser compass (Figure 1). Heywood (1991) recommended that sampling to study SGS should be spread over as large an area as possible to minimize the effects of stochastic variation. In addition, many potential factors may affect SGS in individual plots. Therefore, testing the hypothesis in single plot might be criticized. However, there were few forest stands where the appropriate numbers of individuals of the two Rhododendron species occurred for reliable SGS analyses. Thus, we used a single plot in the forest stand.

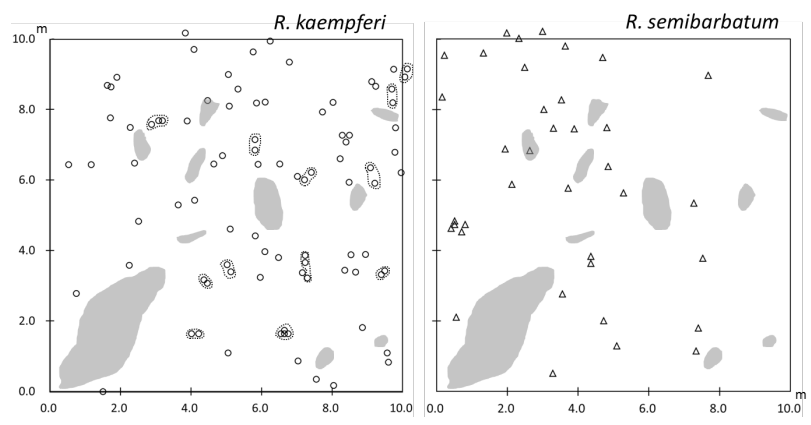

Figure 1

Spatial distribution of the stems of the two Rhododendron species at the study plots. Dotted ranges indicate the clones with multiple stems for R. kaempferi. Ground surface conditions were classified into two categories: soil (area in gray) and litter or sedge.

\section{Sampling and DNA extraction}

We collected fresh leaves for DNA analysis from 89 stems of $R$. kaempferi and 36 stems of $R$. semibarbatum from the study plot in 2012; these included all the stems of the two Rhododendron species in the study plot. Fresh leaves were stored in a freezer at $-20^{\circ} \mathrm{C}$. Total DNA was extracted from approximately $50 \mathrm{mg}$ of leaves using the DNeasy Plant Mini Kit (Qiagen, Tokyo, Japan), according to the manufacturer's instructions.

\section{Primer screening and genotyping of the nuclear microsatellite loci}

For initial screenings, we used 39 nuclear microsatellite loci (simple sequence repeats; SSRs) that were developed for $R$. simsii by Dendauw et al. (2001) and Tan et al. (2009), R. ferrugineum by Delmas et al. (2011), and R. metternichii by Naito et al. (1998) and Kameyama et al. (2002). Of the 39 loci, five polymorphic loci each for $R$. kaempferi and $R$. semibarbatum were used (Table 1). Polymerase chain reaction (PCR) analyses were performed in $10 \mu \mathrm{L}$ volumes. For AZA-0003 and AZA-009 loci, the 
Table 1

Characteristics of the nuclear microsatellite markers used in this study

\begin{tabular}{|c|c|c|c|c|c|c|c|c|}
\hline Locus & $T_{\mathrm{A}}$ & Size range & N & $N_{\mathrm{A}}$ & $H_{0}$ & $H_{\mathrm{E}}$ & $F_{\text {IS }}$ & $f$ (null) \\
\hline \multicolumn{9}{|c|}{ Rhododendron kaempferi } \\
\hline AZA003 & 55 & $140-171$ & 74 & 19 & 0.946 & 0.908 & -0.042 & -0.0260 \\
\hline AZA009† & 55 & $253-310$ & 74 & 12 & 0.243 & 0.724 & $0.665 *$ & 0.4912 \\
\hline N25 & 50 & $199-221$ & 74 & 11 & 0.797 & 0.855 & 0.068 & 0.0329 \\
\hline RM2D5 & 50 & $149-200$ & 74 & 13 & 0.689 & 0.788 & 0.126 & 0.0638 \\
\hline RM3D2 & 46 & $88-113$ & 74 & 8 & 0.743 & 0.760 & 0.022 & 0.0073 \\
\hline \multicolumn{9}{|c|}{ Rhododendron semibarbatum } \\
\hline AZA003 & 55 & $140-152$ & 36 & 3 & 0.556 & 0.557 & 0.003 & -0.0152 \\
\hline AZA009 & 55 & $252-257$ & 36 & 2 & 0.194 & 0.222 & 0.125 & 0.0588 \\
\hline RM2D5 & 50 & $163-216$ & 36 & 6 & 0.611 & 0.691 & 0.117 & 0.0549 \\
\hline RM3D2 & 46 & $109-129$ & 36 & 8 & 0.528 & 0.772 & $0.319 *$ & 0.1813 \\
\hline RM2D2 & 50 & $127-141$ & 36 & 4 & 0.722 & 0.676 & -0.069 & -0.0431 \\
\hline
\end{tabular}

$T_{\mathrm{A}^{\prime}}$ annealing temperature $\left({ }^{\circ} \mathrm{C}\right)$; Size range, $\mathrm{PCR}$ product size range (base pair); $N$, number of multi-locus genotypes (MLGs) analyzed; $N_{\mathrm{A}^{\prime}}$ number of alleles detected; $H_{\mathrm{O}^{\prime}}$ observed heterozygosity; $H_{\mathrm{E}^{\prime}}$ expected heterozygosity; $F_{\mathrm{Is}}$, fixation index; $f$ (null), null allele frequency estimate; ${ }^{*}$ significant deviation of $F_{\mathrm{IS}}$ from zero was tested using 100-120 randomizations $(P<0.05)$; $†$ locus excluded from the analysis of spatial genetic structure.

reaction mixture contained $10 \mathrm{ng}$ genomic DNA, $0.1 \mathrm{mmol} / \mathrm{L}$ of each dNTP, $1 \times$ PCR buffer, $1.5 \mathrm{mmol} / \mathrm{L} \mathrm{MgCl}{ }_{2}, 0.5 \cup$ Ampli Taq Gold (Applied Biosystems, PE Corp., Foster City, CA, USA), and $0.1 \mu \mathrm{mol} / \mathrm{L}$ of each primer. For the other four loci, the mixture contained $10 \mathrm{ng}$ genomic DNA, $0.2 \mathrm{mmol} / \mathrm{L}$ of each $\mathrm{dNTP}, 1 \times$ PCR buffer, $1.5 \mathrm{mmol} / \mathrm{L} \mathrm{MgCl}$, $0.5 \mathrm{U}$ Ampli Taq Gold (Applied Biosystems), and $0.3 \mu \mathrm{mol} / \mathrm{L}$ of each primer. The PCR thermal profile was as follows: an initial denaturing step for $10 \mathrm{~min}$ at $94^{\circ} \mathrm{C}$, followed by 35 cycles of $45 \mathrm{~s}$ at $94^{\circ} \mathrm{C}, 45 \mathrm{~s}$ at the annealing temperature (Table 1), and $45 \mathrm{~s}$ at $72{ }^{\circ} \mathrm{C}$ before a final elongation step at $72^{\circ} \mathrm{C}$ for $7 \mathrm{~min}$; PCR was performed in a GeneAmp 2720 PCR System (Applied Biosystems). The forward sequence of each primer pair was labeled with a fluorescent dye (FAM, PET, or NED). The genotypes were determined using an ABI 3500 Genetic Analyzer and GENEMAPPER ver. 4.1 (Applied Biosystems).

\section{Data analysis}

For clonal identification, clones (MLLs) were determined less stringently using a range of mutation thresholds based on a histogram of pairwise distances; a bimodal distribution of pairwise distances denoted the presence of null alleles, genotypic errors, and somatic mutations (e.g., Douhovnikoff and Dodd, 2003). However, no objective criterion was available (Meirmans and Tienderen, 2004). Therefore, we determined the mutation threshold value $(G)$ according to the recommendation proposed by Schnittler and Eusemann (2010) and presence of bimodality of the histogram of the pairwise distances. Pairwise distances by allelic state under the infinite allele model, which is equivalent to the Manhattan distance for haploid data without missing values, between all the pairs of MLGs were calculated using GENOTYPE (Meirmans and Tienderen, 2004).
For different MLGs, allelic polymorphisms at each nuclear SSR locus were evaluated: total number of alleles detected $\left(N_{A}\right)$, observed heterozygosity $\left(H_{\mathrm{O}}\right)$, expected heterozygosity $\left(H_{\mathrm{E}}\right)$, and null allele frequency estimate [ $f$ (null)], were calculated using CERVUS ver. 3.0 (Kalinowski et al., 2007). Calculation of the fixation index $\left(F_{15}\right)$ and tests for the significant deviation of the $F_{\text {Is }}$ value from zero at each locus using randomizations were performed in FSTAT 2.9.3 (Goudet, 2001).

The SGS was analyzed using SPAGeDi 1.4 c (Hardy and Vekemans, 2002). Four and five loci were used for the analyses of $R$. kaempferi and $R$. semibarbatum, respectively. We used a parameter-kinship coefficient for codominant markers $\left(F_{\mathrm{ij}}\right.$, Loiselle et al., 1995)-computed as a correlation coefficient between allelic states randomly drawn from two different individuals ( $i$ and $j$ ). The kinship coefficient was computed using one stem with the maximum diameter above the ground from each clone. We constructed a correlogram with $95 \%$ confidence intervals for the null distribution that assumes no SGS by obtaining 10,000 permutations in five 3-m distance intervals. For credible estimation, the distance interval was defined, except for the maximum distance interval, according to the guidelines of Hardy and Vekemans (2013). For each distance class, the minimum number of pairs (\#pairs) and the minimum percentage of individuals participating at least once in the interval (\% partic) should be $>100$ and 50, respectively. In addition, the coefficient of variation of the number of times that each individual is represented (CV partic) in each interval was set to $<1$ according to Hardy and Vekemans (2013), except for the fourth and maximum distance interval for R. kaempferi and the maximum distance interval for $R$. semibarbatum. A significant SGS was assessed as an outlier in the observed data from the $95 \%$ confidence intervals. We also calculated the Sp statistic, which is a measure to quantify the SGS, $-b_{\ln } /\left(1-F_{(1)}\right)$, where 


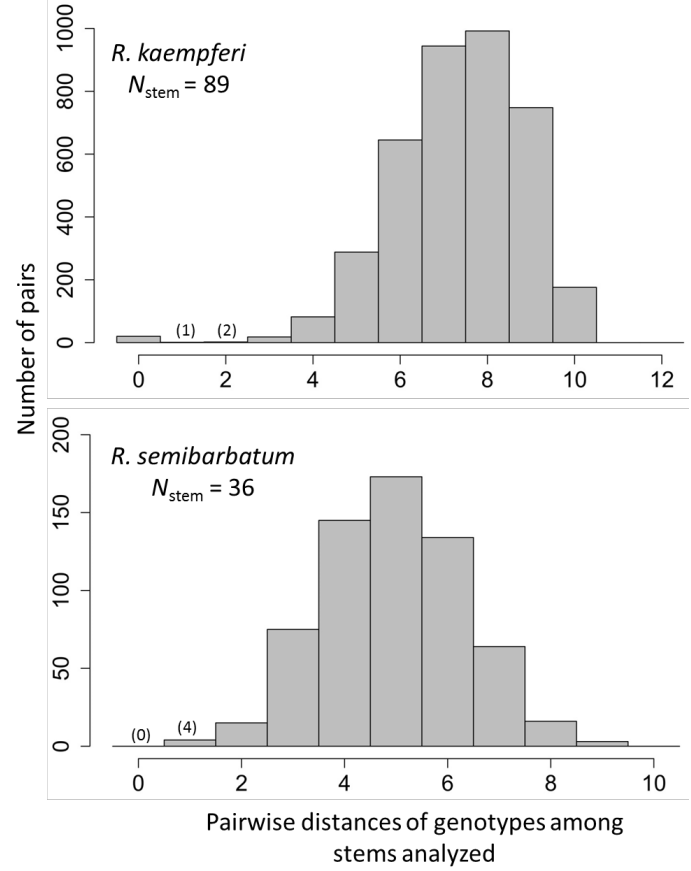

Figure 2

Frequency distribution of all the pairwise distances of genotypes among stems analyzed for the two Rhododendron species. Number of pairs less than 10 is shown in parentheses on the bars; $N_{\text {stem }}$, number of stems used for analysis.
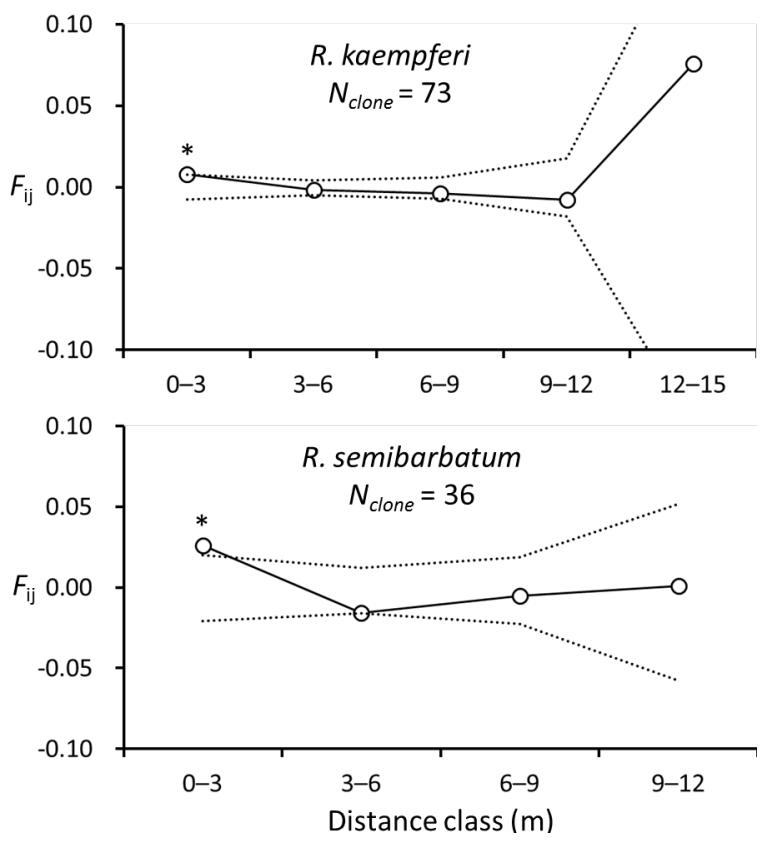

Figure 3

Correlogram of the spatial distribution of the two Rhododendron species. Dotted lines represent $95 \%$ confidence intervals for the null hypothesis, which assumes no genetic structure on the basis of 10,000 randomizations. ${ }^{*} P<0.001$, statistically significant; $N_{\text {clone' }}$ number of clones, from which one stem each were used for analysis $b_{\ln }$ is the slope of the regression of $F_{\mathrm{ij}}$ on the natural logarithm of geographic distance and $F_{(1)}$ is the mean $F_{i j}$ between individuals belonging to the first distance interval (Vekemans and Hardy, 2004).

\section{Results}

\section{Microsatellite markers and clonal identification}

We genotyped the five loci for all 89 stems for $R$. kaempferi and 36 stems for $R$. semibarbatum. The histograms of pairwise distances among stems analyzed for the two Rhododendron species exhibited a bimodal distribution with a low left peak in $R$. kaempferi and unimodal distribution in R. semibarbatum (Figure 2). Therefore, for $R$. kaempferi, we determined the mutation threshold value $(G)=1$ for assigning MLGs to the clones according to the recommendation proposed by Schnittler and Eusemann (2010); in $R$. semibarbatum exhibiting a unimodal distribution, we determined $G=0$. Consequently, 89 stems of $R$. kaempferi consisted of 73 clones with 74 different MLGs and 36 stems of $R$. semibarbatum consisted of 36 clones with 36 different MLGs. Using these different MLGs, we obtained high variability for the nuclear SSR loci: $N_{A}$ and $H_{E}$ ranged from 8 to 19 and 0.243 to 0.946 in R. kaempferi and 2 to 8 and 0.194 to 0.722 in $R$. semibarbatum, respectively. Significant positive deviation of $F_{\text {Is }}$ from zero $(P<0.05)$ and an elevated level for $f$ (null) greater than 0.4 were observed at the AZA009 locus in R. kaempferi (Table 1). Thus, we excluded this locus from the analysis of SGS in R. kaempferi.

\section{Spatial genetic structures}

The correlogram for the 73 stems for $R$. kaempferi and 36 stems for $R$. semibarbatum (one stem from each clone) in the study plot showed significant spatial structures at $0-3-m$ intervals ( $P$ $<0.001)$. The values of $F_{\mathrm{ij}}$ were considerably low, ranging from -0.0078 to 0.0756 for $R$. kaempferi and -0.0159 to 0.0258 for $R$. semibarbatum (Figure 3). The $S p$ statistics for $R$. kaempferi and $R$. semibarbatum were 0.0078 and 0.0185 , respectively.

\section{Discussion}

\section{Spatial genetic structure}

Microsatellite analyses indicated significant SGS in both species at the shortest distance $(<3 \mathrm{~m})$. The $S p$ statistics were approximately twofold higher in R. semibarbatum (0.0185) than in R. kaempferi (0.0078), denoting that $R$. semibarbatum exhibits stronger SGS than $R$. kaempferi. This result is contrary to our expectation that $R$. semibarbatum, producing a larger quantity of lighter seeds than $R$. kaempferi, would exhibit a weaker SGS. Vekemans and Hardy (2004) indicated that plant breeding systems and life forms have a highly significant effect on the Sp statistics, mirroring patterns of SGS. The $S p$ statistics of both species fell within the values of outcrossing (0.0025-0.00227) and self-incompatibility (0.00570.0211). The breeding system of $R$. kaempferi has not yet been reported; however, $R$. semibarbatum has been shown to be 
partially self-incompatible and requires outcrossing for effective seed production (Ono et al., 2008). In addition, considerably low levels of $F_{i j}$ were observed for the two species. These results suggest that outcrossing and possible self-incompatibility can act to purge inbreeding within populations for the two Rhododendron species; therefore, the difference in the intensity of SGS between the two species is not explained by the breeding system. Considering that the two Rhododendron species exhibit the same shrub life form and that restricted gene dispersal by seeds and pollen is the most prevalent driver of SGS (Hamrick and Nason, 1996; Vekemans and Hardy, 2004), the higher level of Sp statistics for R. semibarbatum suggests that seed and/or pollen dispersal of $R$. semibarbatum could be more restricted than that of $R$. kaempferi.

\section{Spatial genetic structure and seed dispersal}

Rhododendron species produce tiny seeds, and hence, their seeds are likely dispersed over a long distance by wind, over at least 30-80 m (Ng and Corlett, 2000; Wang et al., 2014). Further, Rhododendron species are known to require limited microhabitats for germination and seedling establishment; most of their seedlings were restricted to litter-free open sites or Bryophytecovered sites (Cross, 1981; Kameyama et al., 1999; Ng and Corlett, 2000; Suzuki et al., 2000; Morimoto et al., 2003). For species with small seed reserves, such as Rhododendron species, litter acts as a physical barrier for seedling emergence and for seeds to reach the soil. Therefore, the inability of the roots to penetrate the deep litter layer, which inhibits their moisture supply, and burial of small seedlings by litter accumulation result in the hindrance of seedling establishment (Facelli and Pickett, 1991; Lusk, 1995). In fact, at our study site, litter from broadleaved trees and sedge (Carex gifuensis) covered approximately $90 \%$ of the forest floor (Figure 1) under the closed-canopy, and seedlings of the two Rhododendron species were rarely found at this site based on our observations. Species with a large quantity of smaller seeds might have a greater dispersal efficacy than those with larger seeds, but they might contain fewer reserves for supporting seedling establishment and their safe sites for seedling establishment might become more restricted (Schupp, 1995; Tanaka and Kominami, 2002). Therefore, $R$. kaempferi, producing threefold heavier seeds than $R$. semibarbatum, might have more limited seed dispersal, but its safe sites for seedling establishment could be present over a wider range from the mother trees than those of $R$. semibarbatum; in contrast, $R$. semibarbatum might have a greater dispersal efficacy than $R$. kaempferi, but its safe sites could be more restricted around the mother trees. Although more rigorous investigations using additional independent plots for more extrapolation are needed, nonetheless, these ecological consequences might be responsible for the stronger SGS of $R$. semibarbatum than that of R. kaempferi in this study plot.

\section{Spatial genetic structure and pollen limitation}

Pollen limitation is also known to affect SGS; pollen limitation is associated with the density of flowers within a population and the differences in pollinator species (Torres et al., 2003). The two Rhododendron species have different flowering seasons.
The flowering period of $R$. kaempferi is between mid-May and the end of May when other sympatric Ericaceous species, such as R. wadanum, R. quinquefolium, and Enkianthus subsessilis, are also in the flowering stage at our study site; however, the flowering period of $R$. semibarbatum is between the beginning of July and beginning of August (Nakayama et al., 2014). The flowering seasons do not overlap between the two Rhododendron species, and the density of flowers of Rhododendron species in the forest is likely higher at the time when $R$. kaempferi is in the flowering stage than it is for $R$. semibarbatum. This might suggest that pollen limitation can prepensely occur in $R$. kaempferi because many pollinators tend to frequently visit nearby flowers within local patches (Hirao et al., 2006). Given this pollen limitation, R. kaempferi could exhibit stronger SGS than $R$. semibarbatum. However, the opposite result was obtained and $R$. semibarbatum exhibited a stronger SGS than $R$. kaempferi. In addition, the two Rhododendron species depend on insect pollination. At our study site, bumblebee species are the pollinators for flowers of the two Rhododendron species, which is consistent with the findings of previous studies suggesting that the main pollinators for R. semibarbatum are bumblebee species (Ono et al., 2008) and bumblebee species are common pollinators for Rhododendron species (Kudo, 1993; Ng and Corlett, 2000; Mejías et al., 2002). Therefore, we might exclude the possibility that pollen limitation and difference in pollinator species could explain the differences in the intensity of SGS between the two Rhododendron species.

\section{Conclusions}

We presented a case study wherein we comparatively investigated the SGS for two sympatric Rhododendron species having different seed weights in a forest stand using highly variable nuclear microsatellite markers. We found that $R$. semibarbatum exhibited stronger SGS than R. kaempferi. This result might be explained by the ecological consequences of producing lighter seeds than R. kaempferi, which might have more limited seed dispersal. However, safe sites for $R$. semibarbatum seedling establishment could be more restricted around mother trees than those for R. kaempferi, whose safe sites could be more prevalent. The difference in strategies for the trade-off (seed weight vs. site selection) of the two Rhododendron species might reflect the difference in the intensity of SGS in this study plot.

\section{Acknowledgments}

We are grateful to the staff of the Utsunomiya University Forest at Funyu. 


\section{References}

Chung MY, Nason JD, Chung MG (2004) Spatial genetic structure in populations of the terrestrial orchid Cephalanthera longibracteata (Orchidaceae). Amer J Bot 91:52-57. Available at https://doi.org/10.3732/ajb.91.1.52

Cross JR (1981) The establishment of Rhododendron ponticum in the Killarney oakwoods, S.W. Ireland. J Ecol 69:807-824. Available at https://doi.org/ $10.2307 / 2259638$

Delmas CEL, Lhuillier E, Pornon A, Escaravage N (2011) Isolation and characterization of microsatellite loci in Rhododendron ferrugineum (Ericaceae) using pyrosequencing technology. Amer J Bot 98:e120-e122. Available at https:// doi.org/10.3732/ajb.1000533

Dendauw J, De Riek J, Arens P, Van Bockstaele E, Vosman B, De Loose M (2001) Development of sequenced tagged microsatellite site (STMS) markers in azalea. Acta Hortic 546:193-197. Available at https://doi.org/10.17660/actahortic.2001.546.21

Dering M, Chybicki IJ, Rączka G (2015) Clonality as a driver of spatial genetic structure in populations of clonal tree species. J Plant Res 128:731-745. Available at https://doi.org/10.1007/s10265-015-0742-7

Douhovnikoff V, Dodd RS (2003) Intra-clonal variation and a similarity threshold for identification of clones: Application to Salix exigua using AFLP molecular markers. Theor Appl Genet 106:1307-1315. Available at https://doi. org/10.1007/s00122-003-1200-9

Elliott KJ, Vose JM (2012) Age and distribution of an evergreen clonal shrub in the Coweeta Basin: Rhododendron maximum L. J Torrey Bot Soc 139:149166. Available at https://doi.org/10.3159/torrey-d-11-00076.1

Epperson BK (1992) Spatial structure of genetic variation within populations of forest trees. New Forest 6:257-278. Available at https://doi.org/10.1007/ 978-94-011-2815-5 14

Escaravage N, Questiau S, Pornon A, Doche B, Taberlet P (1998) Clonal diversity in a Rhododendron ferrugineum L. (Ericaceae) population inferred from AFLP markers. Mol Ecol 7:975-982. Available at https://doi.org/10.1046/j. 1365-294x.1998.00415.x

Facelli J M, Pickett STA (1991) Plant litter: Its dynamics and effects on plant community structure. Bot Rev 57:1-32. Available at https://doi.org/10.1007/ bf02858763

Goetsch L, Eckert AJ, Hall BD (2005) The molecular systematics of Rhododendron (Ericaceae): A phylogeny based upon RPB2 gene sequences. Syst Bot 30:616-626. Available at https://doi.org/10.1600/0363644054782170

Goudet J (2001) FSTAT, A program to estimate and test gene diversities and fixation indices (Version 2.9.3) [online]. to be found at $<$ http://www2.unil.ch/ popgen/softwares/fstat.htm $>$ [quoted, 16.2.2017]

Hamrick JK, Nason JD (1996) Consequences of dispersal in plants. In: Rhodess Jr OE, Chesser RK, Smith MH (eds) Population dynamics in ecological space and time. Chicago: University of Chicago Press, pp 203-236, ISBN 978 0226710587

Hardy OJ, Vekemans X (2013) SPAGeDi 1.4: a program for spatial pattern analysis of genetic diversity-User's manual [online]. to be found at $<$ http://ebe.ulb. ac.be/ebe/SPAGeDi_files/Manual_SPAGeDi\%20_1-4.pdf > [quated: 23.2.2017]

Hardy OJ, Vekemans X (2002) SPAGeDi: A versatile computer program to analyse spatial genetic structure at the individual or population levels. Mol Ecol Notes 2:618-620. Available at https://doi.org/10.1046/j.1471-8286.2002. $\underline{00305 . x}$

Heywood JS (1991) Spatial analysis of genetic variation in plant populations. Annu Rev Ecol Syst 22:335-355. Available at https://doi.org/10.1146/annurev.es.22.110191.002003

Hirao AS, Kameyama Y, Ohara M, Isagi Y, Kudo G (2006) Seasonal changes in pollinator activities influence pollen dispersal and seed production of the alpine shrub Rhododendron aureum (Ericaceae). Mol Ecol 15:1165-1173. Available at https://doi.org/10.1111/j.1365-294x.2006.02853.x

James EA, McDougall KL (2014) Spatial genetic structure reflects extensive clonality, low genotypic diversity and habitat fragmentation in Grevillea renwickiana (Proteaceae), a rare, sterile shrub from south-eastern Australia. Ann Bot 114:413-423. Available at https://doi.org/10.1093/aob/mcu049

Kalinowski ST, Taper ML, Marshall TC (2007) Revising how the computer program CERVUS accommodates genotyping error increases success in paternity assignment. Mol Ecol 16:1099-1106. Available at https://doi.org/ 10.1111/j.1365-294x.2007.03089.x
Kameyama Y, Isagi Y, Nakagoshi N (2002) Relatedness structure in Rhododendron metternichii var. hondoense revealed by microsatellite analysis. Mol Ecol 11:519-527. Available at https://doi.org/10.1046/j.1365-294x.2002. 01447.x

Kameyama Y, Nakagoshi N, Nehira K (1999) Safe site for seedlings of Rhododendron metternichii var. hondoense. Plant Spec Biol 14:237-242. Available at https://doi.org/10.1046/j.1442-1984.1999.00023.x

Kudo G (1993) Relationship between flowering time and fruit set of the entomophilous alpine shrub, Rhododendron aureum (Ericaceae), inhabiting snow patches. Amer J Bot 80:1300-1304. Available at https://doi.org/ $10.2307 / 2445714$

Loiselle BA, Sork VL, Nason J, Graham C (1995) Spatial genetic structure of a tropical understory shrub, Psychotria officinalis (Rubiaceae). Amer J Bot 82:1420-1425. Available at https://doi.org/10.2307/2445869

Lusk CH (1995) Seed size, establishment sites and species coexistence in a Chilean rain forest. J Veg Sci 6:249-256. Available at https://doi.org/10.2307/ 3236220

Meirmans PG, van Tienderen PH (2004) GENOTYPE and GENODIVE: Two programs for the analysis of genetic diversity of asexual organisms. Mol Ecol Notes 4:792-794. Available at https://doi.org/10.1111/j.1471-8286.2004. 00770.x

Mejías JA, Arroyo J, Ojeda F (2002) Reproductive ecology of Rhododendron ponticum (Ericaceae) in relict Mediterranean populations. Bot J Lin Soc 140:297-311. Available at https://doi.org/10.1046/j.1095-8339.2002.00103.x

Morimoto J, Shibata S, Hasegawa S (2003) Habitat requirement of Rhododendron reticulatum and $\mathrm{R}$. macrosepalum in germination and seedling stages-Field experiment for restoration of native Rhododendron by seedling. J Jpn Soc Reveg Tech 29:135-140 (In Japanese with English Summary). Available at https://doi.org/10.7211/jjsrt.29.135

Naito K, Isagi Y, Nakagoshi N (1998) Isolation and characterization of microsatellites of Rhododendron metternichii Sieb. et Zucc. var. hondoense Nakai. Mol Ecol 7:927-928

Naito K, Isagi Y, Kameyama Y, Nakagoshi N (1999) Population structures in Rhododendron mefternichii var. hondoense assessed with microsatellites and their implication for conservation. J Plant Res 112:405-412. Available at https://doi.org/10.1007/pl00013895

Nakayama C, Aizawa M, Ohkubo T (2014) Leafing and flowering phenology of six shrubby Ericaceous species in deciduous broad-leaved forests in Utsunomiya University Forest in Funyu. Bull Utsunomiya Univ For 50:73-77 (In Japanese)

Nakayama C, Aizawa M, Ohkubo T (2016) Seed production of two Rhododendron (Ericaceae) species in Utsunomiya University Forest at Funyu. Bull Utsunomiya Univ For 52:41-43 (In Japanese)

$\mathrm{Ng} \mathrm{SC}$, Corlett RT (2000) Comparative reproductive biology of the six species of Rhododendron (Ericaceae) in Hong Kong, South China. Can J Bot 78:221229. Available at https://doi.org/10.1139/b99-181

Ono A, Dohzono I, Sugawara T (2008) Bumblebee pollination and reproductive biology of Rhododendron semibarbatum (Ericaceae). J Plant Res 121:319327. Available at https://doi.org/10.1007/s10265-008-0155-y

Schnittler M, Eusemann P (2010) Consequences of genotyping errors for estimation of clonality: A case study on Populus euphratica Oliv. (Salicaceae). Evol Ecol 24:1417-1432. Available at https://doi.org/10.1007/s10682-010-9389-y

Schupp EW (1995) Seed-seedling conflicts, habitat choice, and patterns of plant recruitment. Amer J Bot 82:399-409. Available at https://doi.org/10.2307/ 2445586

Suvanto LI, Latva-Karjanmaa TB (2005) Clone identification and clonal structure of the European aspen (Populus tremula). Mol Ecol14:2851-2860. Available at https://doi.org/10.1111/j.1365-294x.2005.02634.x

Suzuki H, Katsumi N, Kobayashi T, Hasegawa S, Arai M (2000) Environmental factor analysis on the growth of planted tree and the establishment of natural seedling in three species of wild Rhododendron. J Jpn Soc Revege Tech 25:421-426 (In Japanese with English Summary). Available at https://doi. org/10.7211/jisrt.25.421

Tan XX, Li Y, Ge XJ (2009) Development and characterization of eight polymorphic microsatellites for Rhododendron simsii Planch (Ericaceae). Conserv Genet 10:1553-1555. Available at https://doi.org/10.1007/s10592-0089791-y

Tanaka H, Kominami Y (2002) Seed dispersal. In: Nakashizuka T, Matsumoto Y (eds). Diversity and interaction in a temperate forest community; Ecological 
Studies 158. Tokyo: Springer-Verlag, pp 109-125, ISBN 978-4-431-67879-3. Available at https://doi.org/10.1007/978-4-431-67879-3 10

Torres E, Iriondo JM, Escudero A, Pérez C (2003) Analysis of within-population spatial genetic structure in Antirrhinum microphyllum (Scrophulariaceae). Amer J Bot 90:1688-1695. Available at https://doi.org/10.3732/ajb.90.12. $\underline{1688}$

Usui H (1966) Pflanzensoziologischen Untersuchung der Forestgesellshaften. I. Kartographie vom Untersuchungsforstbezirk der Universität Utsunomiya auf pflanzensoziologischer Hinsicht und Forestwissenschaftliche Bedeutung. Bull Utsunomiya Univ For 4:25-58 (In Japanese with German Summary).

Vekemans X, Hardy OJ (2004) New insights from fine-scale spatial structure analysis in plant populations. Mol Ecol 13:921-935. Available at https://doi. org/10.1046/j.1365-294x.2004.02076.x

Wang Y, Wang J, Lai L, Jiang L, Zhuang P, Zhang L, Zheng Y, Baskin JM, Baskin CC (2014) Geographic variation in seed traits within and among forty-two species of Rhododendron (Ericaceae) on the Tibetan plateau: Relationships with altitude, habitat, plant height, and phylogeny. Ecol Evol 4:1913-1923. Available at https://doi.org/10.1002/ece3.1067

Wright S (1943) Isolation by distance. Genetics 28:114-138. 